УДК 621.9.08-52

DOI 10.36910/6775-2313-5352-2020-17-5

Денисюк В.Ю., к.т.н., Симонюк В.П., к.т.н., Лапченко Ю.С., к.т.н., Шибковський І.А.

Луцький національний технічний університет

\title{
МЕТРОЛОГІЧНЕ ЗАБЕЗПЕЧЕННЯ ВИМІРЮВАННЯ МЕХАНІЧНИХ ТА ТРИБОЛОГІЧНИХ ВЛАСТИВОСТЕЙ МАТЕРІАЛІВ НА СУБМІКРОННОМУ І НАНОМЕТРОВОМУ ДІАПАЗОНАХ ЛІНІЙНИХ РОЗМІРІВ
}

В статті проведено огляд методів і приладової бази для дослідження трибологічних $i$ механічних властивостей поверхні. Встановлено, щзо найбільш поширеними методами дослідження иих властивостей на мікро- $і$ нанодіапазонах є контактні методи, засновані на взаємодї твердого наконечника з досліджуваним матеріалом.

У скануючій зондовій мікроскопї для комплексного дослідження трибологічних $i$ механічних властивостей поверхні основним елементом вимірювальних модулів, які використовуються для наноіндентування і склерометрії є біморфний п'єзокерамічний зондовий датчик з алмазним наконечником. Оригінальна конструкція датчика дозволяє реалізувати більше десяти вимірювальних методик на одному приладі.

Робота иих приладів в напівконтактному скануючому зондово-мікроскопічному режимі дозволяє отримати зображення рельєфу поверхні і карту розподілу пружних властивостей. Режим індентування дозволяс виміряти твердість і модуль пружності, оцінити пружне відновлення матеріалу після індентування. Реалізовано метод вимірювання твердості за зображенням відновленого відбитка (метод аналогічний класичному мікроіндентуванню). Реалізовано метод нанесення подряпини з подальшим отриманням зображення рельєфу поверхні відновленого відбитка. Метод дозволяє визначити опір абразивного зномення $i$ твердість матеріалу, адгезію і товщину тонких покриттів.

Ключові слова: твердість, індентор, рельєф, трибометрія, склерометрія, індентування, сканування, зонд, нанотвердомір, датчик.

Постановка проблеми. Зносостійкість $є$ найважливішим експлуатаційним параметром для багатьох виробів, так як безпосередньо впливає на довговічність і надійність їх роботи. Традиційними способами поліпшення трибологічних властивостей виробів $\epsilon$ нанесення на їх поверхню міцних захисних покриттів або модифікація поверхні і приповерхневого шару. Важливим завданням, що стоїть перед сучасною промисловістю, $є$ зменшення глибини зміцнених шарів і створення надтонких покриттів без погіршення споживчих якостей виробу. Обов'язковою умовою для вирішення даного завдання є створення нових засобів і методів дослідження об'єктів на субмікрометровому і нанометровому діапазонах лінійних розмірів.

Для проведення механічних випробувань традиційно використовуються контактні методи. До них відносяться: метод вдавлювання індентора в матеріал (індентування), метод нанесення подряпин (склерометрія), метод багатоциклового стирання поверхні наконечником. Кожен з вищевказаних методів має певні обмеження щодо їх застосування в залежності від механічних і геометричних властивостей досліджуваної поверхні об'єкту. Ув'язка різнорідних даних отриманих при макро-, мікро- і нано- випробуваннях в єдину картину, що описує поведінку матеріалів і покриттів при їх експлікації $є$ актуальною науково-технічною задачею.

Аналіз останніх досліджень і публікацій. Скануюча зондова мікроскопія (СЗМ) - один 3 найбільш поширених методів дослідження поверхні і поверхневих властивостей зразків в мікро- і нанометровому діапазонах. СЗМ дозволяе проводити дослідження, у вакуумі, на повітрі і в рідині як на провідних, так і на непровідних поверхнях. Основними елементами конструкції СЗМ є зонд, система переміщення зонда і реєструюча система. Реєструюча система фіксує величину сигналу, що залежить від відстані між зондом і зразком. Система негативного зворотного зв'язку обробляє реєстроване значення і підтримує постійну величину сигналу, керуючи положенням зразка або зонда.

До основних типів СЗМ відносяться: атомно-силові мікроскопи, тунельні мікроскопи, ближньопольні оптичні мікроскопи.

Робота атомно-силового зондового мікроскопа заснована на взаємодії поверхні зразка 3 наконечником, що розташований на кінці пружної консолі, яка називається кантилевером (рис. 1, а). Ван-дер-Ваальсові сили притягування і сили електростатичного відштовхування,

(C) Денисюк В.Ю., к.m.н., Симонюк В.П., к.т.н., Лапченко Ю.С., к.m.н., Шибковський І.А. 
однойменно заряджених електронних оболонок атомів зонда і зразка, викликають вигин кантилевера. Вигин контролюється системою з лазера і секторного фотодетектора (рис. 1, б).

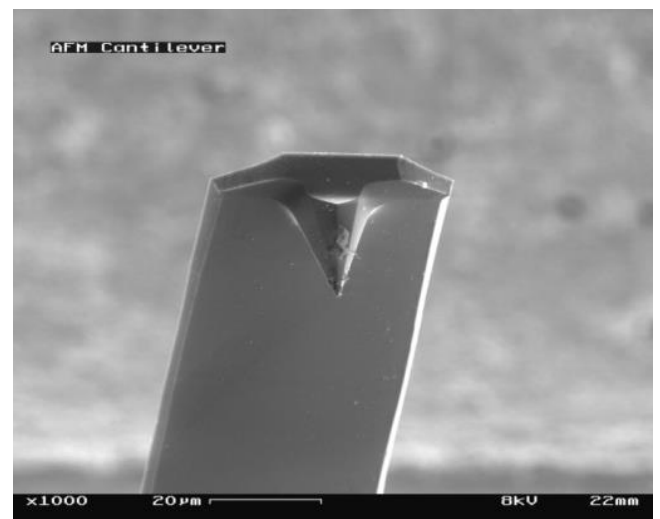

a)

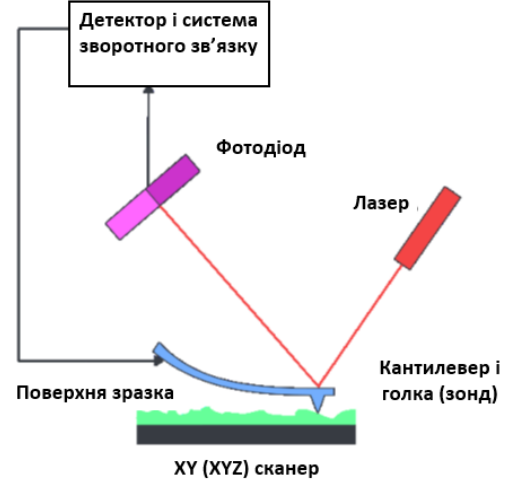

б)

Рис. 1. Растрове електронно- мікроскопічне зображення кантилевера (а), схема реєстрації відгину кантилевера (б)

Модульні СЗМ дозволяють конфігурувати вимірювальний прилад під конкретну вузькоспеціалізовану задачу. На платформі INTEGRA (рис. 2) реалізовано близько 40 вимірювальних методик.

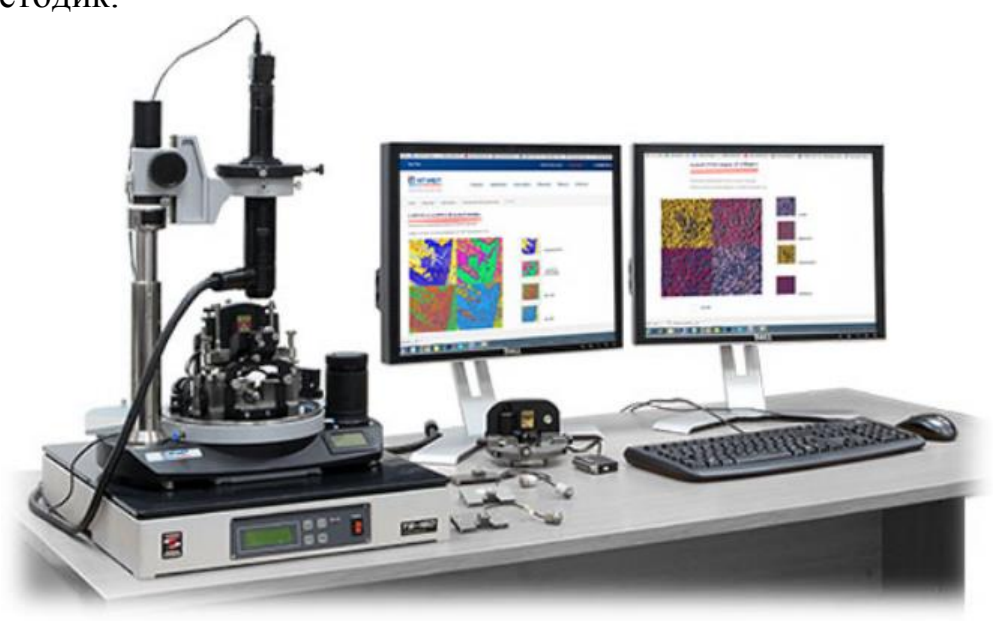

Рис. 2. СЗМ Інтегра Прима

Але даний СЗМ мають ряд недоліків. Одним з недоліків є невелике поле сканування (декілька сотень мікрометрів) і малий максимально допустимий перепад висот на зразку (декілька десятків мікрометрів). Інша проблема пов'язана 3 формою наконечника, його геометрією і радіусом заокруглення вістря. Наявність гострих виступів або западин призводить до неправильного відображення рельєфу поверхні при скануванні, відбувається «самосканування» наконечника (конволюція форми наконечника і рельєфу поверхні). Процес отримання СЗМ-зображення, як правило, тривалий. Оперативно проводити вимірювання (в реальному часі) важко, можливо не на всіх матеріалах i не у всіх умовах. Значний час накопичення даних призводить до спотворення СЗМ-зображень в зв'язку з температурним дрейфом зразка і деталей мікроскопа, що додає помилку у вимірюванні рельєфу [1].

Скануючий зондовий мікроскоп-нанотвердомір «НаноСкан-3D» (рис. 3) багатофункціональне аналітичне обладнання, призначене для дослідження рельєфу поверхні, механічних і електричних властивостей. У приладі реалізовані методи вивчення рельєфу і структури поверхонь на субмікронному і нанометровому діапазонах лінійних розмірів, а також вимірювання механічних властивостей: вимірювання твердості методами наноіндентування [12], склерометрії [2, 13] і мікроіндентування [12], вимірювання модуля пружності методами наноіндентування [12] і силової спектроскопії $[5,6]$, вимірювання тріщиностійкості методами індентування та склерометрії [7], вимірювання зносостійкості і коефіцієнта тертя методами нанесення подряпин i циклічного стирання [8], вимірювання згинальної жорсткості

(C) Денисюк В.Ю., к.m.н., Симонюк В.П., к.т.н., Лапченко Ю.С., к.m.н., Шибковський І.А. 
мікроконструкції [9]. Також реалізовані методи вимірювання поверхневого електричного опору об'ємних матеріалів і тонких плівок контактними однозондовими методами 3 високою локальністю проведення вимірювань [10].

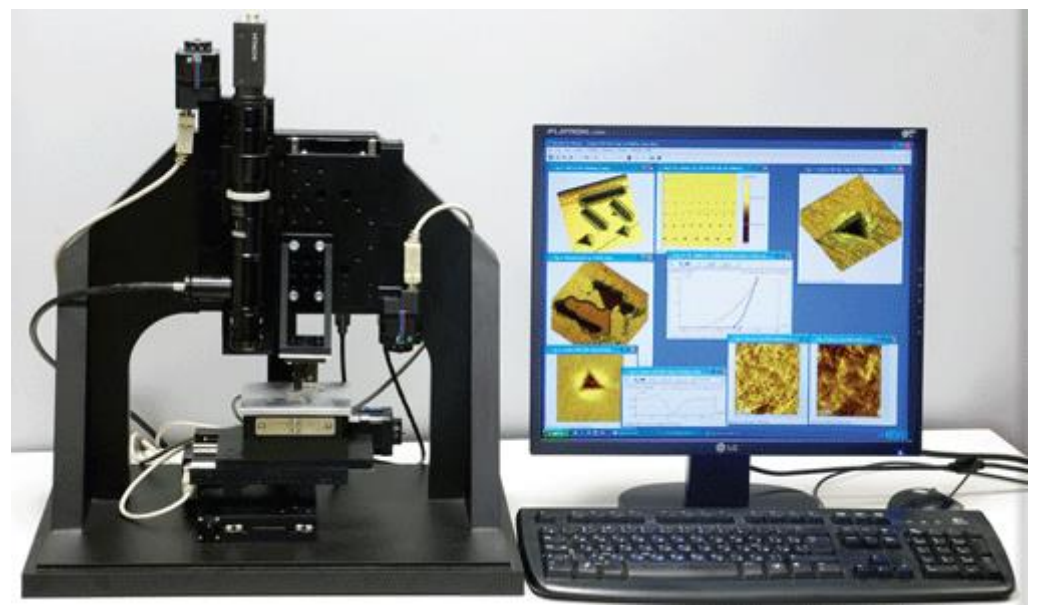

Рис. 3. Скануючий зондовий мікроскоп-нанотвердомір «НаноСкан-3D»

Мета роботи. Розроблення комплексу експериментально-теоретичних підходів до дослідження механічних та трибологічних властивостей матеріалів, що реалізуються на субмікронному і нанометровому діапазонах лінійних розмірів, порівняння одержуваних $з$ їх допомогою результатів 3 традиційними трибологічними випробуваннями, а також дослідження можливості застосування цих підходів при аналізі трибомеханічних властивостей матеріалів при технологічному контролі матеріалів 3 певними властивостями.

Викладення основного матеріалу. Робота приладу «НаноСкан-3D» заснована на принципах скануючої зондової мікроскопії, основним чутливим елементом приладу $\epsilon$ п’єзорезонансний зонд 3 високою згинальною жорсткістю консолі. Робота в режимі резонансних коливань дозволяє здійснювати контроль контакту вістря 3 поверхнею за двома параметрами: за амплітудою $A$ і частотою $F$ коливань зонда. Це дозволяє розрізняти в'язку і пружну компоненту взаємодії зонда 3 поверхнею, дозволяє відрізнити пружну поверхню від вузького забруднення на ній (виникає на відкритому повітрі), а також вимірювати механічні властивості поверхонь.

Висока згинальна жорсткість зонда дозволяє проводити механічні випробування шляхом механічної модифікації поверхні досліджуваного зразка. Реєстрований механічний відгук матеріалу дозволяє вимірювати його фізичні властивості: міцність і пружність.

Конструкція зонда дозволяє використовувати різноманітні наконечники, в тому числі алмазні індентори різної форми (пірамідальні, сферичні тощо).

Сканування поверхні. Скануючий нанотвердомір «НаноСкан-3D» дозволяє отримувати зображення тривимірного рельєфу поверхні методом скануючої зондової мікроскопії. Сканування виконується построково в напівконтактному режимі алмазним наконечником, закріпленим на п'єзокерамічному зонді. Зонд здійснює резонансні коливання на частоті $F \sim 10$ кГц 3 амплітудою $A<50$ нм. У процесі сканування система зворотного зв'язку підтримує постійну частоту $F$ або амплітуду $A$ коливань зонда.

Використання різних опорних значень зворотного зв'язку призводить до отримання різних за змістом зображень однієї і тієї ж ділянки (рис. 4).

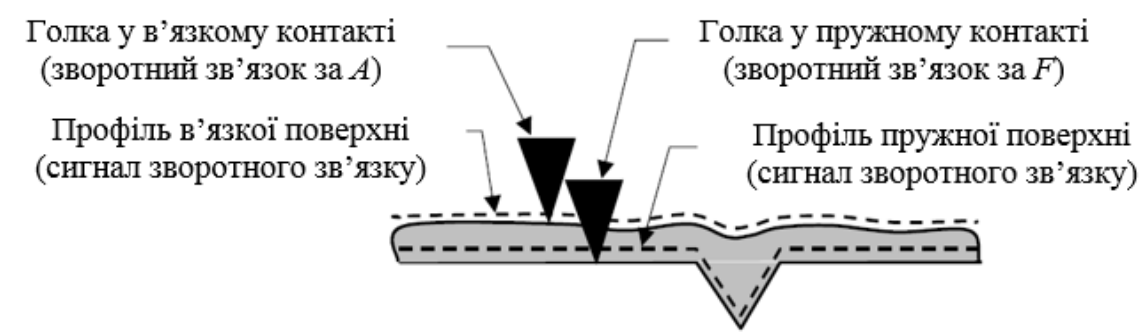

Рис. 4. Схема контакту голки з поверхнею при різних режимах роботи зворотного зв'язку

(C) Денисюк В.Ю., к.т.н., Симонюк В.П., к.т.н., Лапченко Ю.С., к.m.н., Шибковський І.А. 
У режимі сканування за частотою забезпечується постійна жорсткість області контакту індентора $з$ поверхнею. У цьому режимі зручно досліджувати матеріали з відносно високими значеннями твердості і модулем пружності (метали і сплави, кристалічні матеріали, кераміки). При цьому виключається або суттєво зменшується вплив присутності забруднення на поверхні зразка (рис. 5, а). У режимі сканування за амплітудою $A$ профіль поверхні, в деякому наближенні відповідає постійній величині в'язких та інших втрат, що дозволяє вивчати м'які матеріали (полімери, пластики), мінімізувавши механічний вплив наконечника на зразок (рис. 5, б).

a)

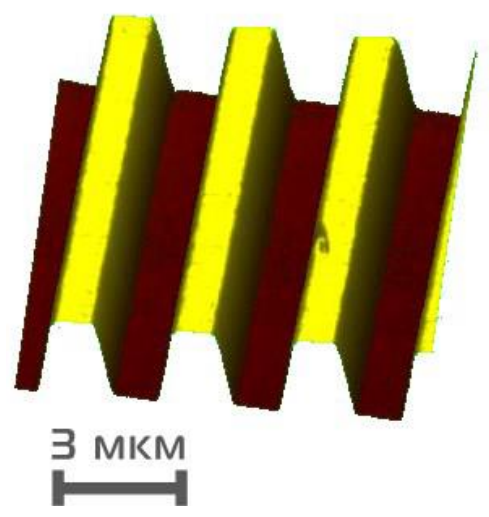

б)

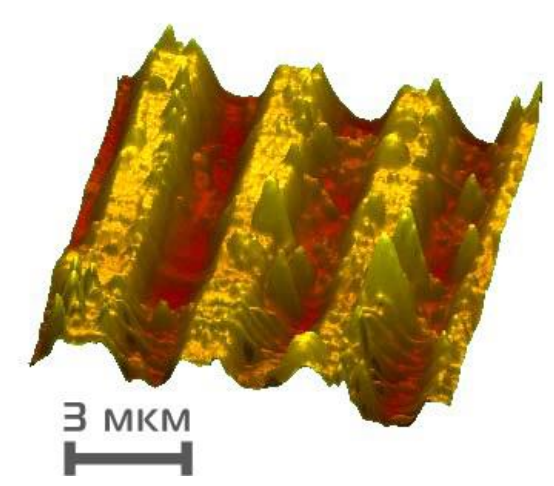

Рис. 5. СЗМ-зображення тестової міри періоду і висоти TGZ02:

a) сканування зі зворотним зв'язком за частотою: зображення пружної («чистої») поверхні; б) сканування зі зворотним зв'язком за амплітудою: зображення в'язкої (забрудненої) поверхні

Вимірювання карт механічних властивостей. Коливальний режим роботи зонда дозволяє отримувати крім зображення рельєфу додаткову інформацію про структуру та механічні властивості досліджуваних зразків. У процесі сканування одночасно $з$ висотою рельєфу записується зміна вільного параметра коливань зонда (при скануванні 3 постійною частотою $F$ вільний параметр - амплітуда $A$, і навпаки). Отримане зображення являс собою карту розподілу в'язкопружних властивостей по поверхні. Даний режим дозволяє вивчати структуру багатофазних матеріалів, а також розподіл механічних неоднорідностей по поверхні. Карта розподілу механічних властивостей, що отримується в процесі сканування, $є$ відносною і дає тільки якісну інформацію про абсолютні значення механічних параметрів.

На рис. 6 представлені зображення рельєфу поверхні і карта модуля пружності полікристалічного високочистого ніобію. Поверхня зразка травленню не піддавалася. Карта пружного модуля більш інформативна, ніж топографія рельєфу і дозволяє однозначно визначити межі зерен $\mathrm{i}$ ïх розмір.

a)

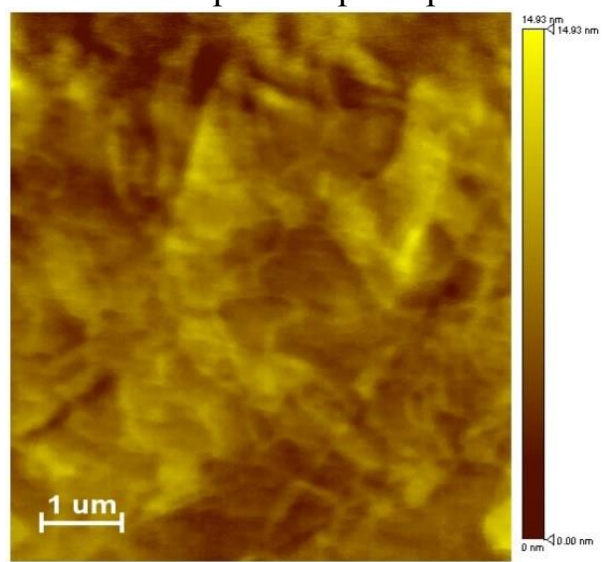

б)

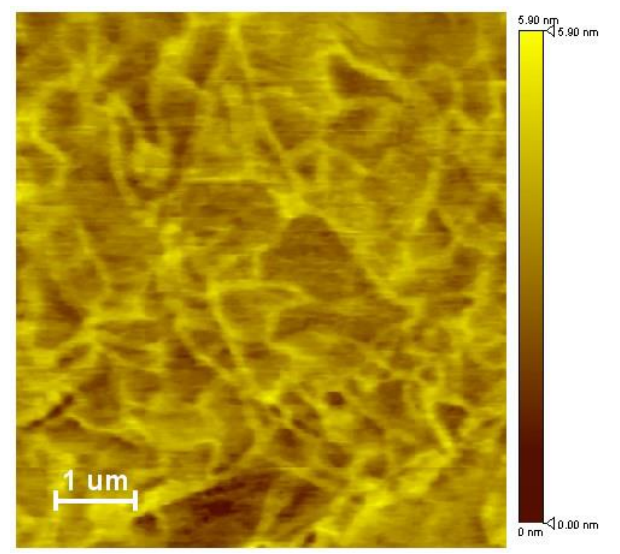

Рис. 6. Полікристалічний високочистий ніобій, полірована поверхня: a) рельєф поверхні; б) карта пружного модуля

Наноіндентування. У скануючому нанотвердомірі «НаноСкан-3D» реалізований метод наноіндентування, у якому випробування на втискання алмазного наконечника проводиться тим же датчиком, що і сканування рельєфу. Це дає можливість вибрати місце і провести випробування з точною прив'язкою до отриманого зображення рельєфу поверхні (рис. 7).

(C) Денисюк В.Ю., к.т.н., Симонюк В.П., к.т.н., Лапченко Ю.С., к.m.н., Шибковський І.А. 
a)

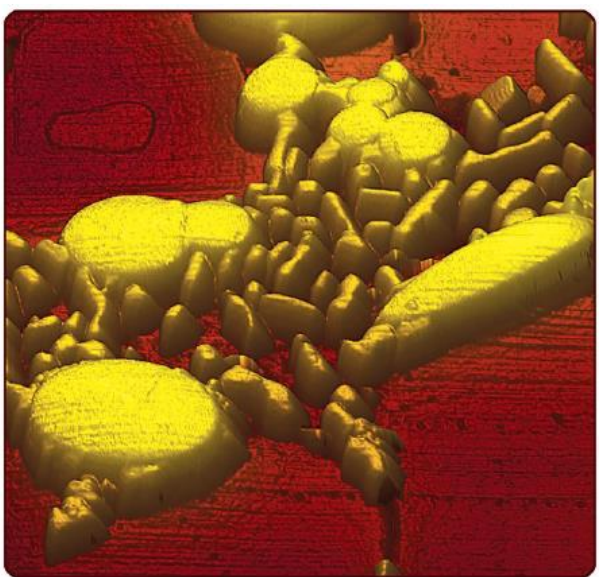

б)

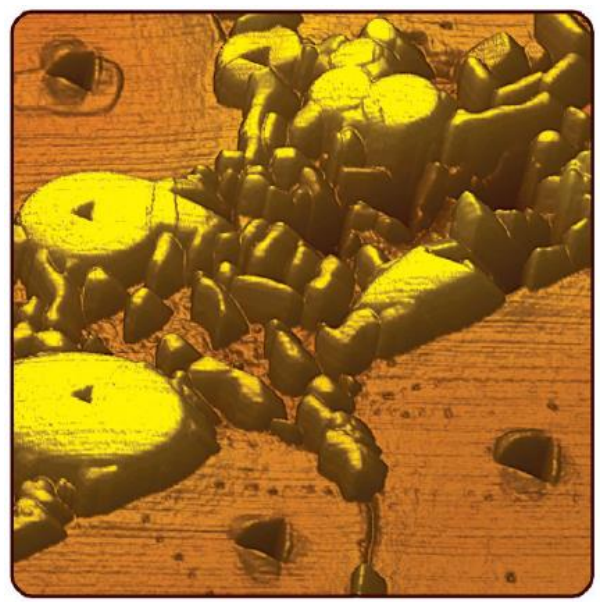

Рис. 7. Локальне вимірювання механічних властивостей методом наноіндентування: a) СЗМ-зображення рельєфу поверхні до випробування; б) СЗМ-зображення рельєфу поверхні після випробування

Метод дозволяє вимірювати величину твердості і модуля пружності матеріалу. Також наноіндентування використовують для оцінки повзучості, пружного відновлення, тріщиностійкості матеріалів; товщини і однорідності покриттів і приповерхневих шарів.

Вимірювання твердості за зображсенням відновленого відбитка. Метод аналогічний класичному методу мікроіндентування, в якому твердість визначається 3 аналізу оптичного зображення відновленого відбитка [4]. Вимірювання площі відбитка на субмікронному i нанометровому діапазонах обмежується роздільною здатністю оптичних мікроскопів. В цьому випадку дуже ефективним способом є застосування методів СЗМ, що дозволяють отримувати тривимірні зображення відновлених відбитків 3 нанометровою просторовою роздільною здатністю. Аналіз тривимірного СЗМ-зображення дозволяє виявити і потім врахувати особливості деформації матеріалу при індентуванні (утворення навалів, тріщин, пружне відновлення) (рис. 8) [6].

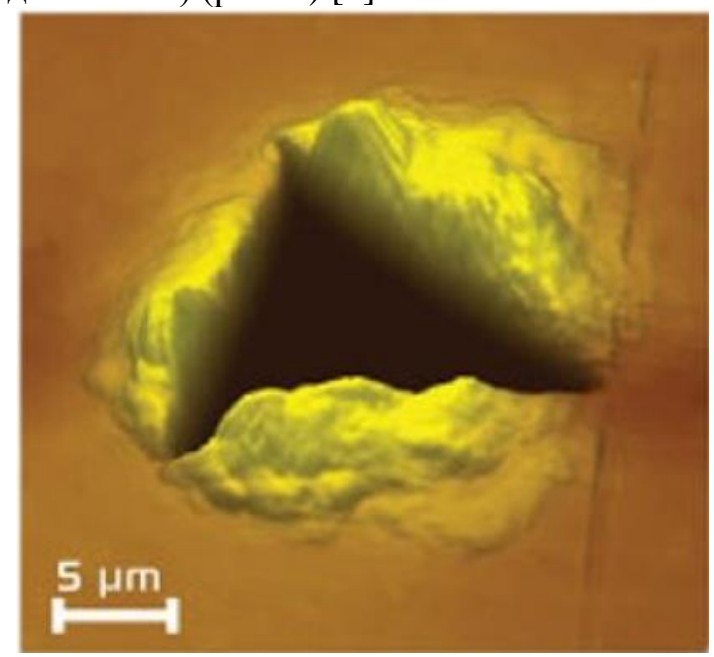

a)

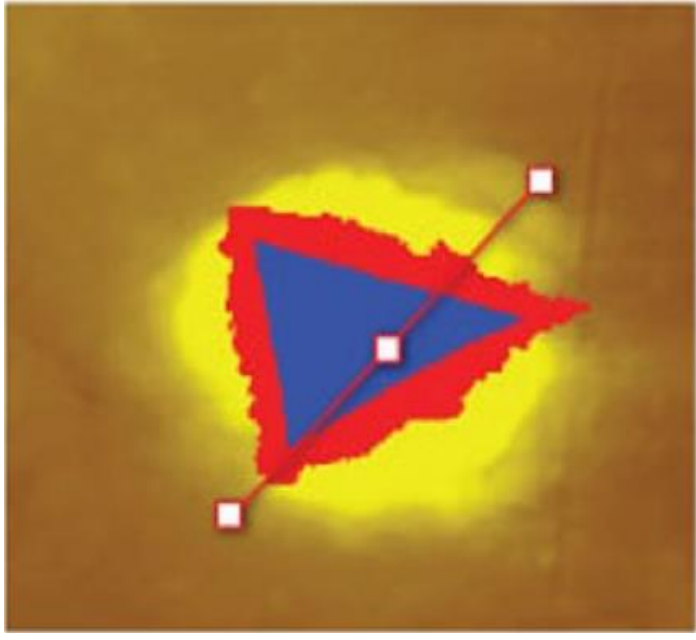

б)

Рис. 8. Зображення відбитка на поверхні сталі У10, навантаження - $50 \mathrm{мH}$ :

a) СЗМ-зображення рельєфу; б) виділення площі проєкції відбитка (синім) і площі навалів по його периметру (червоним)

Значення твердості в методі розраховується за формулою Мейєра [4] $з$ урахуванням поправки на площу утворених навалів:

$$
H=\frac{P_{\max }}{A_{\text {проскиіявідбитку }}+A_{\text {плоча навалів }}}
$$

(C) Денисюк В.Ю., к.m.н., Симонюк В.П., к.m.н., Лапченко Ю.С., к.m.н., Шибковський І.А. 
і являє собою відношення максимального прикладеного до індентора навантаження до площі проєкції відбитка, яка вимірюється за його СЗМ-зображенням.

Склерометрія. Вимірювання твердості методом склерометрії полягає в нанесенні подряпин на поверхні зразка 3 подальшим іiі скануванням і аналізом отриманого зображення (рис. 9) [13].

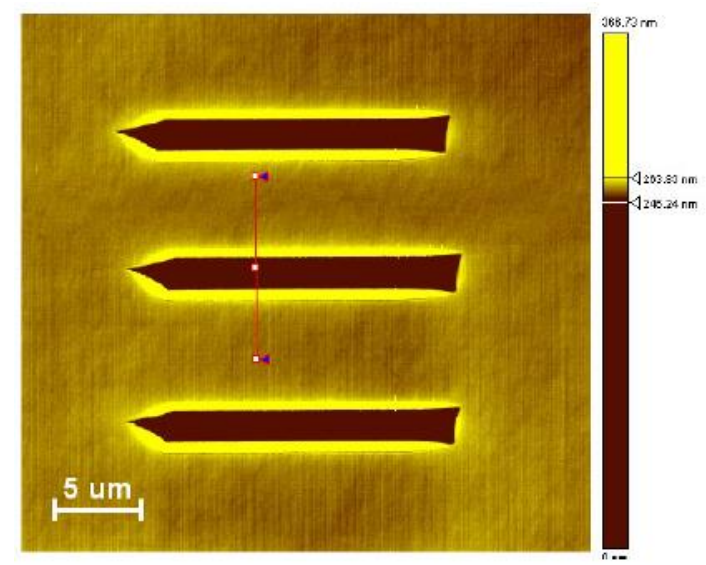

a)

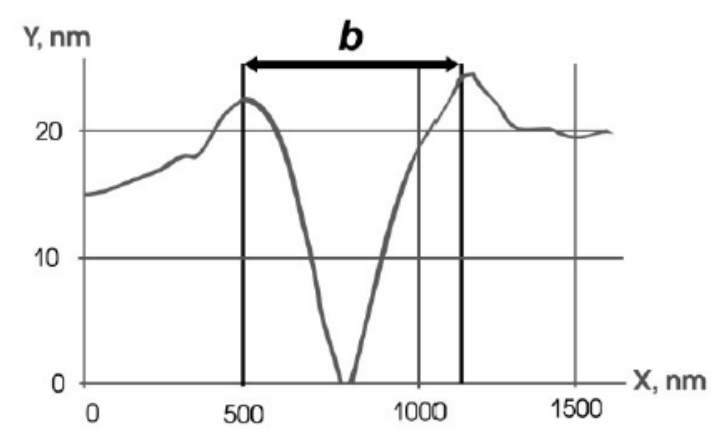

б)

Рис. 9. Вимірювання твердості методом склерометрії:

а) СЗМ-зображення подряпини; б) схема визначення ширини подряпини

Значення твердості досліджуваного матеріалу визначають за формулою:

$$
H=k \cdot \frac{P}{b^{2}},
$$

де $P$ - нормальне зусилля, 3 яким була нанесена подряпина, виражене в Ньютонах; $b-$ середньоарифметичне значення ширини подряпини, виражене в метрах; $k$ - коефіцієнт форми індентора для даної ширини подряпини.

Коефіцієнт форми індентора $k$ визначають, наносячи подряпини на міру (матеріал 3 відомою твердістю), і розраховують за формулою:

$$
k=\frac{H_{E} b^{2}}{P},
$$

де $H_{E}$ - значення твердості міри, каліброваної незалежним способом.

Метод склерометрії також застосовується для визначення деяких параметрів тонких плівок. Нанесення подряпин зі змінним навантаженням (рис. 10) і подальша візуалізація його сліду дає можливість визначити відразу декілька параметрів плівки в рамках однієї вимірювальної процедури: область пружної взаємодії, порогове навантаження, при якому починається пластична деформація (з'являється видимий слід на поверхні), навантаження відшарування або початку крихкого руйнування тонкої плівки і ії товщину.

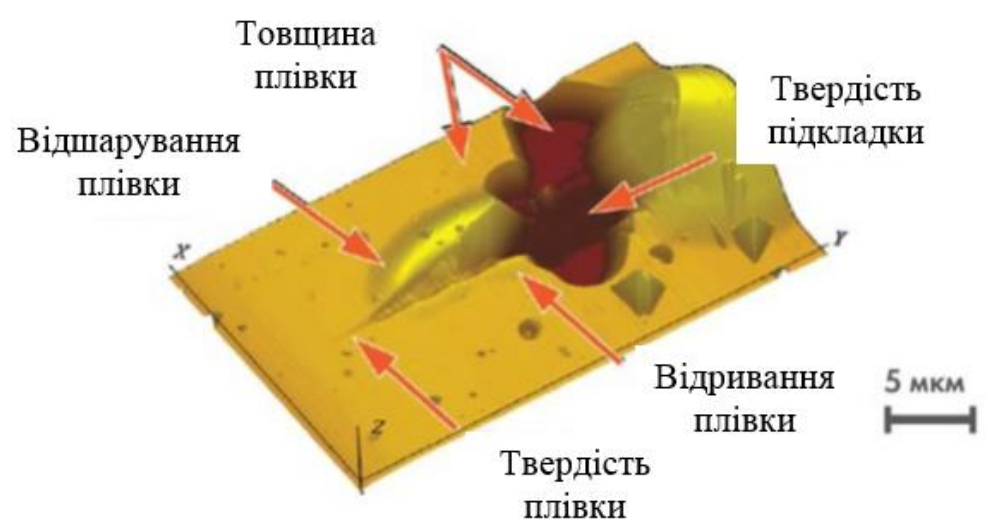

Рис. 10. Подряпина, зі змінним навантаженням, нанесена на тонку алмазоподібну плівку на кремнієвій підкладці 
Силова спектроскопія. Вимірювання модуля пружності методом силової спектроскопії полягає у вимірюванні частоти коливань зонда з закріпленою на кінці голкою, при втисканні голки в поверхню зразка. Коли голка торкається поверхні, резонансна частота змінюється внаслідок дії сил пружного відштовхування (рис. 11). Зміна частоти записується для кожного положення зонда. Отримана залежність являє собою криву підведення (рис. 12).

Криві підведення для різних матеріалів мають різний нахил. Нахил кривої пропорційний значенню модуля пружності матеріалу в області контакту (рис. 13).

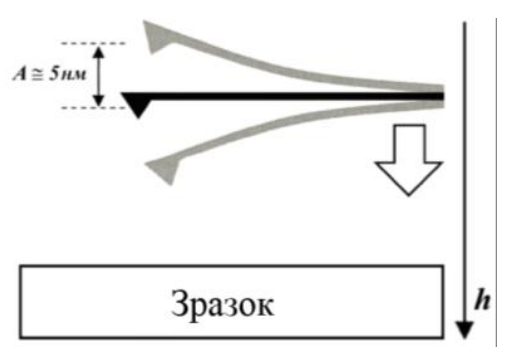

Рис. 11. Схема проведення вимірювань методом силової спектроскопії

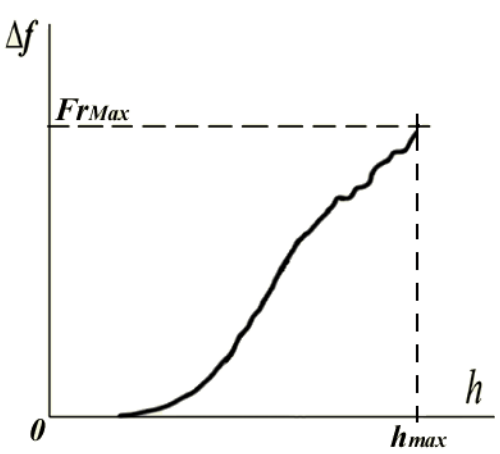

Рис. 12. Загальний вигляд кривої підведення

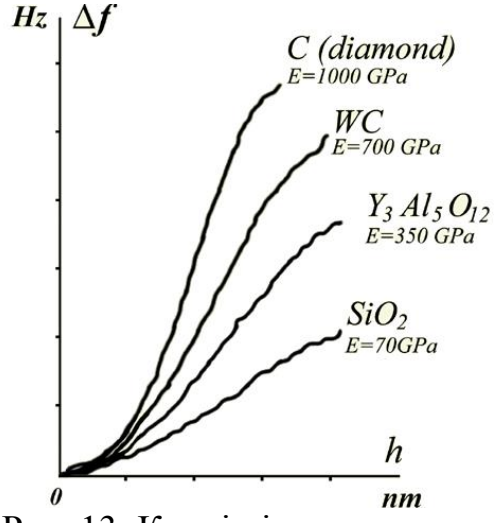

Рис. 13. Криві підведення для різних матеріалів

Перед вимірюванням прилад калібрується на матеріалах порівняння 3 відомим (виміряним незалежним способом) значенням модуля пружності. Потім крива підведення вимірюється для досліджуваного матеріалу. Шукане значення модуля пружності визначається за відомим значенням модуля пружності еталонного матеріалу і співвідношенню кутів нахилу робочих ділянок кривих підведення для досліджуваного і еталонного матеріалу.

Вимірювання жорсткості мікромеханічних систем. Для контролю жорсткості балок (рис. 14) і мембран (рис. 15) використовується режим вимірювання залежностей навантаженняпереміщення, аналогічний методу інструментального наноіндентування. Реалізовано також режим багаторазового навантаження об'єкта індентором. В результаті такого випробування, можна визначити жорсткість (податливість) мембрани або балки, максимальний прогин мембрани, число циклів навантаження до руйнування.
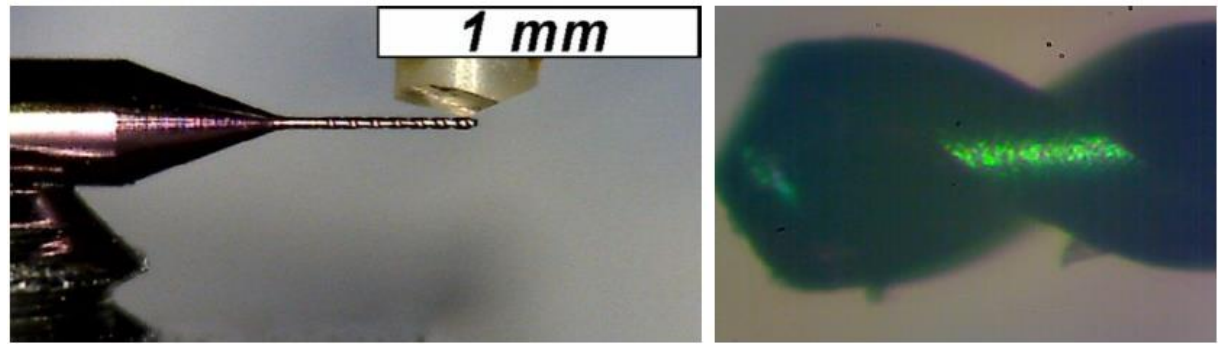

Рис. 14. Вимірювання жорсткості мікросверла покритого алмазоподібною плівкою (діаметр 100 мкм)
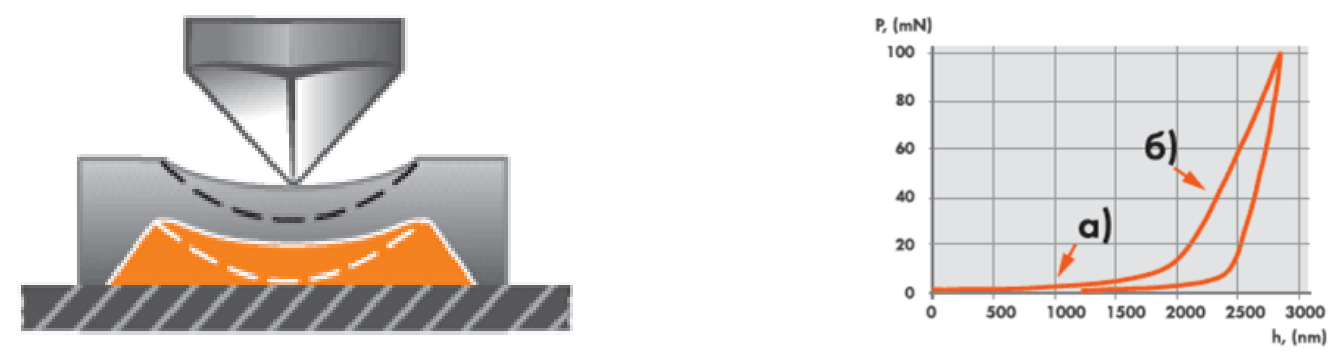

Рис. 15. Схема вимірювання властивостей мембрани і експериментальна крива навантаженнярозвантаження: жорсткість і прогин мембрани (а), мембрана впирається в підкладку (б) 
Для точного позиціонування місця навантаження в «НаноСкан-3D» застосовується цифровий оптичний мікроскоп з високою роздільною здатністю, а також режим попереднього сканування поверхні об'єкта в режимі скануючої зондової мікроскопії.

Висновки. Запропоновано комплексний підхід, що дозволяє встановити взаємозв'язок трибологічних властивостей покриттів і матеріалів 3 проведеними результатами, вимірювання досліджуваного матеріалу методами, індентування, склерометрії і СЗМ за допомогою єдиного п'єзокерамічного датчика 3 високочистим або напівпровідниковим алмазним наконечником в субмікронному i нанометровому діапазонах. Отриманню найкращого результату сприяє використання комплексу методів, на якому будуть реалізовані всі приведені вище експериментальні методи із застосуванням єдиного датчика. Розроблений комплекс вимірювальних методик і підходів слід використовувати при дослідженні різних нових матеріалах: композиційні матеріали, тверді, пружні і крихкі покриття на твердих кристалічних і м'яких полімерних підкладках.

Функціональні можливості скануючого нанотвердоміра «НаноСкан-3D» дозволяють реалізувати на його базі різні механічні випробування, такі як метод наноіндентування, метод склерометрії (нанесення подряпин), метод циклічного стирання поверхні. Модульна система дозволяє замінювати або вбудовувати нові елементи в конструкцію приладу, що дозволяє розширити область його застосування або підготувати прилад для проведення оригінальних експериментів.

\section{Інформаційні джерела}

1. Миронов В.Л. Основы сканирующей зондовой микроскопии Учебное пособие для студентов старших курсов высших учебных заведений. Нижний Новгород, $2004-110$ c.

2. Усеинов А., Усеинов С. Измерение механических свойств методом царапания Контроль и измерения // Наноиндустрия. № 6. 2010. С. 28-32.

3. Гоголинский К.В., Львова Н.А., Усеинов А.С. Применение сканирующих зондовых микроскопов и нанотвердомеров для изучения механических свойств твердых материалов на наноуровне (обобщающая статья) // Заводская лаборатория. Диагностика материалов. Т. 73, № 6. 2007. - C.28-36.

4. Григорович В.К. Твердость и микротвердость металлов. М.: Наука, 2006. -230 с.

5. Усеинов А.С. Измерение модуля Юнга сверхтвердых материалов с помощью сканирующего зондового микроскопа «НаноСкан» // Приборы и техника эксперимента. №1. 2004. - C. 134.

6. Усеинов С.С. и др. Особенности применения метода наноиндентирования для измерения твердости на наномасштабе // Нанотехника. № 13. 2008. - С. 111-115.

7. Усеинов А., Кравчук К., Маслеников И. Индентирование. Измерение твердости и трещиностойкости покрытий // Наноиндустрия. № 45(7). 2013. - С. 48-57.

8. Усеинов А.С., Кравчук К.С., Русаков А.А. Комплексное исследование физикомеханических и трибологических свойств сверхтонких гальванических покрытий // Мир гальваники. № 3(19). 2011.- С. 51.

9. Королева В.А. и др. Оценка изгибной жесткости и деформации микроразмерных исполнительных элементов устройств микросистемной техники // Нано- и микросистемная техника. № 1. 2011.- С. 39-42.

10. Сошников А.И. и др. Измерение локального удельного сопротивления методами наноиндентирования и силовой спектроскопии // Приборы и техника эксперимента. № 2. 2013. C. $120-126$.

11. Шибковський I.А., Денисюк В.Ю., Ковалюк Ю.І. Комплексне дослідження трибологічних властивостей на субмікронному і нанометровому діапазонах / Матеріали IV-ï Всеукраїнської науково-практичної конференції «Приладобудування та метрологія: сучасні проблеми, тенденції розвитку» 29-30 жовтня 2020 р.): збірник тез. - Луцьк : Луцький НТУ, 2020.- C. 100-102.

12. Oliver W.C., Pharr G.M. An improved technique for determining hardness and elastic modulus using load and displacement sensing indntation experiments // J. Mater. Res. Vol. 7, № 6. 2002. - P. 1564.

13. Useinov A.S., Useinov S.S. Scratch hardness evaluation with in-situ pile-up effect estimation // Philos. Mag. Vol. 92, № 25. 2012. - P. 3188-3198. 
Денисюк В.Ю., к.Т.Н., Симонюк В.П., к.Т.Н., Лапченко Ю.С. к.Т.Н., Шибковський И.А. Луцкий национальный технический университет

\section{МЕТРОЛОГИЧЕСКОЕ ОБЕСПЕЧЕНИЕ ИЗМЕРЕНИЯ МЕХАНИЧЕСКИХ И ТРИБОЛОГИЧЕСКИХ СВОЙСТВ НА СУБМИКРОННОМ И НАНОМЕТРОВОМ ДИАПАЗОНАХ ЛИНЕЙНЫХ РАЗМЕРОВ}

В статье проведен обзор методов и приборной базы для исследования трибологических и механических свойств поверхности. Установлено, что наиболее распространенными методами исследования этих свойств на микро- и нанодиапазоне есть контактные методы, основанные на взаимодействии твердого наконечника с исследуемым материалом.

В сканирующей зондовой микроскопии для комплексного исследования трибологических и механических свойств поверхности основным элементом измерительных модулей, которые используются для наноиндентирования и склерометрии является биморфный пьезокерамический зондовый датчик с алмазным наконечником. Оригинальная конструкция датчика позволяет реализовать более десяти измерительных методик на одном приборе.

Работа этих приборов в полуконтактном сканирующем зондово-микроскопическом режиме позволяет получить изображение рельефа поверхности и карту распределения упругих свойств. Режим индентирования позволяет измерить твердость и модуль упругости, оценить упругое восстановление материала после индентирования. Реализован метод измерения твердости по изображению восстановленного отпечатка (метод аналогичен классическому микроиндентуванню). Реализован метод нанесения иарапины с последуюшим получением изображения рельефа поверхности восстановленного отпечатка. Метод позволяет определить сопротивление абразивному износу и твердость материала, адгезию и толщину тонких покрытий.

Ключевые слова: твердость, индентор, рельеф, трибометрия, склерометрия, индентирование, сканирование, зонд, нанотвердомер, датчик.

\section{Denysiuk, V. Symonyuk, Y. Lapchenko, I. Shibkovsky}

Lutsk National Technical University

\section{METROLOGICAL PROVISION MEASUREMENT OF MECHANICAL AND TRIBOLOGICAL PROPERTIES OF MATERIALS ON SUBMICRON AND NANOMETRIC DIACHIOR}

The article reviews the methods and instrumentation for the study of tribological and mechanical properties of the surface. It is established that the most common methods for studying these properties in the micro and nanodranges are contact methods based on the interaction of the hard tip with the material under study.

In scanning probe microscopy for the complex study of tribological and mechanical properties of the surface, the main element of the measuring modules used for nanoindentation and sclerometry is a bimorph piezoceramic probe sensor with a diamond tip. The original design of the sensor allows to implement more than ten measuring techniques on one device.

The operation of these devices in the semi-contact scanning probe-microscopic mode allows to obtain images of the surface relief and a map of the distribution of elastic properties. The indentation mode allows to measure hardness and modulus of elasticity, to estimate elastic recovery of material after indentation. The method of measuring hardness according to the image of the restored imprint ( $a$ method similar to classical microindentation) is implemented. The method of scratching is implemented, followed by obtaining image of the relief of the surface on the restored imprint. The method allows to determine the abrasion resistance and hardness of the material, adhesion and thickness of thin coatings.

Keywords: hardness, indenter, relief, tribometry, sclerometry, indentation, scanning, probe, nanohardness tester, sensor.

(C) Денисюк В.Ю., к.т.н., Симонюк В.П., к.т.н., Лапченко Ю.С., к.m.н., Шибковський І.А. 